Marquette University

e-Publications@Marquette

$1-1-2010$

Money, Money, Money - How do Attitudes Toward Money Impact Vanity and Materialism? the Case of Young Chinese Consumers

Srinivas Durvasula

Marquette University, srinivas.durvasula@marquette.edu

Steven Lysonski

Marquette University, steven.lysonski@marquette.edu

Accepted version. Journal of Consumer Marketing, Vol. 27, No. 2 (2010): 169-179. DOI. (C) 2010

Emerald. Used with permission. 


\title{
Money, money, money - how do attitudes toward money impact vanity and materialism? - the case of young Chinese consumers
}

\author{
Srinivas Durvasula \\ Marquette University \\ Milwaukee, WI \\ Steven Lysonski \\ Marquette University \\ Milwaukee, WI
}

\begin{abstract}
:
Purpose - China is undergoing a radical change as the forces of industrialization and modernization transform its society. Money is taking on an increasingly important role, particularly among young Chinese, as the Western ideals of individualism and hedonism thrive. The goal of this research is to understand attitudes towards money in China and how these attitudes affect elements of consumer behavior such as materialism and vanity.

Design/methodology/approach - The paper uses a well-accepted scale (with several dimensions) to explore attitudes towards money. Research questions examine how the dimensions of attitudes towards money affect materialism and achievement vanity. The sample comprises 127 young Chinese consumers. Statistical results based on confirmatory factor analysis as well as path analysis are reported.

Findings - The findings clearly show that attitudes towards money in China are not monolithic; instead there are variations among young Chinese. Materialism is affected by the power-prestige and anxiety dimensions, but unaffected by the distrust dimension of money attitudes. Achievement vanity is affected by the power- prestige dimension of money attitudes.
\end{abstract}


NOT THE PUBLISHED VERSION; this is the author's final, peer-reviewed manuscript. The published version may be accessed by following the link in the citation at the bottom of the page.

Research limitations/implications - Future research could examine other developing countries and other generational consumer segments. Another future research topic is to develop a comprehensive model of money attitudes, materialism, vanity, compulsive buying, and their possible antecedents or moderators.

Practical implications - These findings offer insight into the mindset of young Chinese. Beliefs that money permits one to attain not only status and possessions, but also power and control over others are contributing to increased materialism and expressions of vanity among young Chinese. For marketers, the results imply that positioning products based on the possession of money and the use of this money to indulge hedonism may resonate well with young Chinese consumers. However, some of the relationships we found may cause concern to ethicists and consumer watchdogs because of the associated problems of compulsive buying and other problems which are prevalent in consumer societies.

Originality/value - So far, no study has examined whether money attitudes drive materialism and achievement vanity, especially among younger consumers in developing countries such as China.

Keywords: Youth, China, Money, Consumer behaviour

\section{Introduction}

The accumulation, possession, and spending of money is central to modern market- driven cultures. Simmel (1997) in writing his voluminous book, The Philosophy of Money, illustrates in great detail how money shapes the mentality of consumers both in their actions and in their psyches. According to Simmel, money plays a huge sociological role on the social and cultural interactions of a society. As a society becomes obsessively driven by money it shapes many spheres of a consumer's life. Indeed, money may develop into a psychological force whereby it serves as a means to some end - that end could be materialism or vanity. In today's China, money is taking on an increasingly important role as the Western ideals of individualism and hedonism flourish (Johansson, 2001). This research paper is focused on the views towards money in China and how these views are connected to materialism and vanity.

Money can permit extravagances and new identities to develop for consumers since money can signify prestige. In effect, money has more than just an economic meaning; it has a social meaning that

Journal of Consumer Marketing, Vol 27, No. 2 (2010): pg. 169-179. DOI. This article is (C) Emerald and permission has been granted for this version to appear in e-Publications@Marquette. Emerald does not grant permission for this article to be further copied/distributed or hosted elsewhere without the express permission from Emerald. 
allows consumers to emulate each other in their choice and use of consumer goods (Doyle, 1999; Veblen, 1976). Crump (1992) proposes that money represents a "deep ritual" that reflects the endless facets of the culture in which it appears, and its possession has a profound impact on consumers. Crump (1981) also envisions money as a symbolic system that permits individuals to convert money into whatever "sacred symbols" it chooses. Marketers can portray money's symbolism and power in the way lifestyles and possessions are featured (i.e., positioned) according to those who possess the money to live such lifestyles. These portrayals can serve as motivators for consumers to buy certain products as money contributes to the development and identification of the self (Doyle, 1999). In contrast, social reformers may wish to critique obsession with money and its power to acquire possessions as something that is dysfunctional to society and to the individual. Simmel (1997) argues that money is responsible for impersonal relations between people, and the possession of money allows for one to satisfy the ideal of distinction. Of importance to this research is how young Chinese consumers are affected by money.

China is undergoing an unprecedented metamorphosis as it evolves from a Communist society with government planning to one that is more market driven and consumer oriented. In the wake of this dramatic change, the psyche of Chinese consumers may be changing as well. In particular, money, its possession and its pursuit, has taken on a more important role. Rosen (2004) captures this idea in stating that in China "the path to upward mobility is becoming increasingly skewed by the triumph of the new money-driven values and practices". One study found that almost 50 percent of Chinese perceived that money was either as important as or more important than friendship and that money was either as important as or more important than ideas (Rosen, 2004). As a parallel, McClelland (1961) found a dramatic change in Russian children from 1925 to 1950 as a new political ideology stressed individual achievement over passive dependence on authority (Doyle, 1999). Presently, China, too, is emphasizing individual achievement versus passive conformity to Communist ideals.

The popular press has documented the new income classes that have appeared in China over the last decade and the mania for money

Journal of Consumer Marketing, Vol 27, No. 2 (2010): pg. 169-179. DOI. This article is (C) Emerald and permission has been granted for this version to appear in e-Publications@Marquette. Emerald does not grant permission for this article to be further copied/distributed or hosted elsewhere without the express permission from Emerald. 
making (Fan, 2007; Marquand, 2004; Yue, 2007). High-income classes command enormous buying power allowing them to possess whatever they wish from expensive cars to posh apartments. Undoubtedly, as Chinese youth observes this preoccupation with money by these income classes, they too are changing. The nouveaux riche have become the role models for youth in society (Rosen, 2004; Wang, 2005). In youth magazines in China, which serve as socialization agents for high school students, the subject of money and how to make it is pervasive. Rosen (2004) interprets this development as demonstrating that money has become an important topic in China; the young are being encouraged to seek it, acquire it, and flaunt it. Another recent development demonstrating the preeminence of money in China is the emergence of the "Bobo" subculture or segment (Wang, 2005). A Bobo is one who "demands the best from life, seeks products of exquisite taste and quality, and chooses products that display character". In essence, a Bobo pursues money so that he/she can indulge in a form of materialism and vanity that was unheard-of in the past.

Given the center stage that money now occupies in China, how young people in China are changing is of concern not only to marketers who wish to sell to them but to consumer protection advocates and social reformers who wish to protect them. The goal of this paper is to investigate how attitudes towards money in Chinese youth are linked to their levels of materialism and vanity. Is money a driving force in shaping their levels of materialism and vanity in Chinese society among young consumers?

\section{The psychology of money}

To understand how young Chinese are affected by money, one needs to examine how the importance of money has been conceptualized in other societies. The psychology of money is perhaps the least studied topics in the field of psychology (Furnham and Argyle, 1998). The lack of a sufficient body of knowledge on money attitudes prompted some researchers to state unequivocally that more information exists on sexual behavior than on money behavior (Wiseman, 1974). From the consumers' point of view, however, the topic of money is very important to people of all ages. Studies have shown that even five-year-old children in the USA are interested in the topic of money. These very young consumers' fascination with money

Journal of Consumer Marketing, Vol 27, No. 2 (2010): pg. 169-179. DOI. This article is (C) Emerald and permission has been granted for this version to appear in e-Publications@Marquette. Emerald does not grant permission for this article to be further copied/distributed or hosted elsewhere without the express permission from Emerald. 
is so apparent that they show no hesitation and require no prompting in their money-related responses (Lau, 1998). A total of 75 percent of teenagers are emphatic that a "very important" reason for going to college is to make more money. This is up from 39 percent who responded in a similar fashion in 1971 (Roberts and Jones, 2001).

Among 19 different topics, "becoming very well off financially" now ranks number one for college students. As adults, 14 percent of consumers ranked money as most important, while 62 percent ranked money among the top three when asked to rank the importance of politics, sex, money, family, work, and income (Rubenstein, 1981). Even though some consumers may consider money to be corrupting and repulsive, many others desire and admire it (Freud, 1959). Lack of money may be perceived by money admirers as a threat to their safety, thereby giving rise to depression and emptiness (Abraham, 1965). To summarize, while money is a motivator for most consumers (Gupta and Shaw, 1998), it is a hygiene factor for others (Pfeffer, 1998).

Understanding money attitudes is thus essential because these attitudes shape human behavior, especially, purchasing behavior. Extant research, mostly limited to the discipline of human resources, shows that money attitudes have an impact on consumers' spending habits, political ideology, and their attitudes toward the environment (Roberts et al., 1999). According to Tang (1992), people's attitude towards money may influence their work performance, reward systems, and their intrinsic motivation to perform any task. Money attitudes also have an impact on pay satisfaction for both low paid and high paid employees (Thozhur et al., 2006). In contrast, and contrary to intuition, individual characteristics (e.g., age, education, gender) were found to be inconsistent predictors of pay satisfaction (Crosby, 1982; Keaveny and Inderrierden, 2000; Shaw et al., 1999). Money attitudes also affect people's motivation, well-being, and interpersonal relationships (Furnham and Lewis, 1986). Employers use money as an instrument to motivate their employees because money significantly affects employee behavior, performance, and organizational effectiveness (Tang et al., 2000).

Of great importance to marketers and consumer protection advocates, consumers' money attitudes are positively associated with compulsive buying. One group of consumers that is most vulnerable to

Journal of Consumer Marketing, Vol 27, No. 2 (2010): pg. 169-179. DOI. This article is (C) Emerald and permission has been granted for this version to appear in e-Publications@Marquette. Emerald does not grant permission for this article to be further copied/distributed or hosted elsewhere without the express permission from Emerald. 
compulsive buying is today's young adults. They were brought up in a culture of indebtedness and instant gratification (Lea et al., 1995). Recent research by Roberts (1998) found increasing levels of compulsive buying among young adults in the USA. Such compulsive buying, in turn, has been linked to depression, anxiety, and low selfesteem (Roberts and Jones, 2001). It has also contributed to personal finance problems, personal bankruptcy filings, and credit card debt. Recent statistics show that among young adults, nearly 9 percent have filed for bankruptcy as compared to less than 1 percent having done that a few years earlier (Roberts and Jones, 2001; McBride, 1997). While no such statistics are available for China, the popular press has highlighted the developing obsession for money in China as noted in earlier discussion.

Beyond compulsive buying, money attitudes are also likely to play a pivotal role in affecting other psychological tendencies among consumers. Since the possession and acquisition of money can be a driving force for a consumer, it may be linked to other forces within the psyche. Money is clearly more than a symbol of wealth as it may allow one to gratify other motives. In particular, money attitudes are likely to be associated with one's level of materialism. Materialism represents the belief in the importance of material for one's identity, goals, and purpose in life. And, money enables one to fulfill materialistic impulses. As Madonna expressed in her prescient lyrics about money and materialism in the 1980s in the USA:

They can beg and they can plead

But they can't see the light, that's right

cause the boy with the cold hard cash

Is always mister right, cause we are

Chorus:

We are living in a material world

And I am a material girl

You know that we are living in a material world

And I am a material girl.

These lyrics above seem particularly germane to what is happening in China today as young people have discovered the allure of money and its meaning in contemporary society.

Journal of Consumer Marketing, Vol 27, No. 2 (2010): pg. 169-179. DOI. This article is (C) Emerald and permission has been granted for this version to appear in e-Publications@Marquette. Emerald does not grant permission for this article to be further copied/distributed or hosted elsewhere without the express permission from Emerald. 
NOT THE PUBLISHED VERSION; this is the author's final, peer-reviewed manuscript. The published version may be accessed by following the link in the citation at the bottom of the page.

We expect attitudes towards money to be associated with materialism among young Chinese consumers. Furthermore, a preoccupation with achievement vanity (i.e., excessive preoccupation with professional achievements) may also condition one to look for ways to indulge this materialistic tendency. Vanity can be fulfilled by having access to the resources to satisfy such feelings; the possession of money becomes integral to this drive. In light of these arguments, we examined the role that money attitudes play in their associations with materialism and achievement vanity among young consumers as China develops economically. Our research is in response to the call for additional research on the changing values and attitudes in China and the need for more research on the metamorphosis in the Chinese mindset. Since no study has explicitly established a link among these three concepts, our study adds to the existing body of knowledge on this under-researched topic by focusing on a country where money has only recently become a paramount goal.

Previous studies that implied a relationship between money attitudes and materialism were conducted within the USA. Our study extends all previous research by collecting data from young Chinese consumers and examines the link between money attitudes, materialism and vanity. Studying young consumers is appropriate because this group of consumers is significantly affected by the problem of compulsive buying. Since China has a vast pool of young consumers, numbering over 300 million according to some estimates, performing a study on consumers of this country has implications concerning globalization. In particular, as China progresses from a Communist country to one with open markets, attitudes towards money are likely to become much more significant as a driving force in modern China.

\section{Background research on money attitudes, materialism, and achievement vanity}

\section{Money attitudes}

There has been considerable interest in measuring attitudes towards money. Earlier research on money attitudes established that money has many meanings (Snelders et al., 1992; Tang et al., 2000). These meanings include good (i.e., "money is important", "money can buy luxuries"), evil ("money is shameful"), respect ("money can bring 
in many friends"), budget ("I use my money carefully"), and freedom ("money means power"). Perhaps, the best conceptualization and measurement of money attitudes was the scale developed by Yamuchi and Templer (1982). They captured the essence of the various meanings of money in their money attitude scale (MAS). This scale has been validated as a multi-dimensional scale with four important dimensions as follows:

1. "power-prestige" - those scoring high on this dimension use money as a tool to influence and impress others and as a symbol of success;

2. "retention time" - those scoring high on this dimension plan for their financial future and monitor their financial situation closely;

3. "distrust" - those scoring high are hesitant, suspicious, and doubtful regarding situations involving money and have a lack of faith in their ability to make efficient purchase decisions; and

4. "anxiety" - those scoring high see money as a source of anxiety as well as a source of protection from anxiety.

In this study, we measure money attitudes using MAS given its validation in the literature. Since our focus is on young adults, the "retention-time" dimension that deals with financial planning is not relevant to our study. Parenthetically, Roberts and Jones (2001) also did not use the retention dimension because they did not consider items of the retention-time dimension appropriate for young adults (e.g., "I save now to prepare for my old age"). Hence, our study will only examine power-prestige, distrust, and anxiety dimensions of the MAS scale.

The limited amount of research on money attitudes in the marketing discipline has established a strong relationship between money attitudes and compulsive buying (Roberts and Jones, 2001). On the basis of money attitudes, this stream of research classified consumers into three groups:

1. those who view money as a tool to gain power;

Journal of Consumer Marketing, Vol 27, No. 2 (2010): pg. 169-179. DOI. This article is (C) Emerald and permission has been granted for this version to appear in e-Publications@Marquette. Emerald does not grant permission for this article to be further copied/distributed or hosted elsewhere without the express permission from Emerald. 
2. those who show suspicion and distrust when dealing with money; and

3. those who consider money as a source of anxiety and as a protector from anxiety.

These three groups correspond to the dimensions discussed above.

Consumers who view money as a tool of power unhesitatingly use money to either impress or dominate people (Goldberg and Lewis, 1978). One way those consumers exhibit their social power is by buying material goods. Status consumption and accumulation of materialistic goods allow them to feel socially powerful. Unfortunately, status consumption is a competitive and comparative process. To the extent that other consumers also signal their social power via possession of material goods, the level of goods required to make a powerful social statement keeps increasing, leading to ever increasing consumption of goods, materialism, and compulsive buying (Bell, 1998). Studies by d'Astous and Tremblay (1989), and Roberts (1998) found a strong link between social status associated with buying and compulsive buying. It is no wonder then that marketers employ status appeals as the second most frequently used motivator behind price appeals in advertising. Consumers who view money as a tool for power score high on the power-prestige dimension of MAS.

In terms of money attitudes, the second type of consumer is those who show hesitation, distrust, and suspiciousness when dealing with money. Such consumers are likely to have limited skills in making sound purchases. These consumers are typically price sensitive. They do not have the ability to make efficient purchases, and are unlikely to be compulsive buyers. Consumers who show lack of trust in dealing with money are rated highly on the distrust dimension of MAS.

The third type of consumer represents those who view money as a source of anxiety. These consumers engage in compulsive buying to alleviate expeditiously their anxiety (Valence et al., 1988). Escape from anxiety is the primary motivator for consumers who exhibit addictive buying behavior. Consumers who view money as a source of anxiety repeatedly shop and spend money to reduce anxiety (Desarbo and Edwards, 1996). Such consumers score high on the anxiety dimension of the MAS scale.

Journal of Consumer Marketing, Vol 27, No. 2 (2010): pg. 169-179. DOI. This article is (C) Emerald and permission has been granted for this version to appear in e-Publications@Marquette. Emerald does not grant permission for this article to be further copied/distributed or hosted elsewhere without the express permission from Emerald. 
NOT THE PUBLISHED VERSION; this is the author's final, peer-reviewed manuscript. The published version may be accessed by following the link in the citation at the bottom of the page.

\section{Materialism and money attitudes}

Materialism can be conceptualized in various ways including devotion to material needs and desires, as a mindset focused on getting and spending, or as the attachment one has to worldly possessions (Richins and Dawson, 1992). Those high in a materialistic ethos place possessions and their acquisition at the center of their being and tend to judge their own success and those of others by the material wealth accumulated. The relevance of materialism to marketing and consumers has been well established in the literature, especially with the widely quoted article dealing with its measurement by Belk (1985). Since then, metrics to gauge one's level of materialism have been well codified by others (Richins and Dawson, 1992). Materialism has been investigated in many consumer research investigations indicating its importance in understanding consumer behavior. We posit that materialism is linked to attitudes towards money since acquisition or ownership of money allows one to engage in materialistic pursuits.

Existing research suggests that those consumers who are likely to use money as a tool of power are likely to acquire material goods to demonstrate their social power. Consumers who score high on the power and prestige dimension regarding money view money instrumentally as a means to influence and impress others and as a statement of their success. These consumers can use money for vanity reasons by displaying their achievement via the possessions that they own such as expensive homes, cars, jewelry, and the like.

Furthermore, consumers with such an orientation can also indulge their materialistic ideals since money represent the means to material acquisitions. Clearly, the association of power and prestige with both vanity and materialism is based on the psychological tendencies that foster vanity and materialism.

Consumers who view money as a source of anxiety indulge in excessive purchase of goods to reduce their anxiety. Those who are high in anxiety regarding money view possession of money as having the power to make them feel secure or, conversely, make them feel insecure if they have insufficient money. The possession of money allows one to gratify materialistic urges or impulses, resulting in a pacified state. Those who are materialistic but lack sufficient money to indulge or satisfy their materialistic leanings may feel inadequate, 
ungratified, and anxious that they cannot buy what they wish to possess. Hence, those with the means to buy can placate their materialistic urges while those without the means will feel insecure or unhappy that they cannot act on their materialistic drive.

In contrast, consumers who are distrustful of money are unlikely to indulge in excessive purchasing. They are also unlikely to spend a significant portion of their money on purchases. Those consumers are likely to be hesitant, suspicious and doubtful regarding situations involving money and do not believe that they have good judgment when they spend their money. The reason for this outcome is that those who are high in distrust are not likely to view money as a tool that allows them to fulfill their identities or flaunt their successes with material goods they purchased with money. Instead, these people see money in a negative way in that matters involving money are risky and likely to have negative consequences for them. Money in fact may be viewed as "the root of all evils" to such people. Therefore, their attitudes towards money are not associated with materialism since they are likely not to be materialistic people.

The research expectations stated below capture our understanding of how these money attitudes and materialism are related:

RE1. There will be a significant relationship between powerprestige dimension of MAS and materialism for young Chinese.

RE2. There will be a significant relationship between the anxiety dimension of MAS and materialism for young Chinese.

RE3. There will be an insignificant relationship between the distrust dimension of MAS and materialism for young Chinese.

\section{Achievement vanity and money attitudes}

The theme of achievement has been at the core of most cultures. Spenner and Featherman (1978) define achievement as an accomplishment when compared against performance standards. Achievement, for example, refers to worldly success in terms of accumulation of academic credentials, attainment of social status, and financial success. Achievement vanity refers to excessive preoccupation with achievements. Achievement vanity can easily be seen when consumers use consumption as a way of demonstrating granted for this version to appear in e-Publications@Marquette. Emerald does not grant permission for this article to be further copied/distributed or hosted elsewhere without the express permission from Emerald. 
status, success or conspicuous consumption (Dholakia and Levy, 1987). Through the possession of products, consumers can display how their personal achievement produced their successes. Belk (1985) and Solomon $(1985,1992)$ suggest that these consumers display their success or status by consuming products or services in a conspicuous manner. Similarly, Richins and Dawson (1992) provide evidence that consumers' materialism is used as a symbol of achievement. It is important to point out that the studies referenced above are based on American culture.

In contrast and until recent times, the display of wealth in China was neither possible nor allowed given the Communist ideals. Now that free enterprise is encouraged by the government, consumers are likely to become more materialistic or achievement driven as a way to show their success in the "new order" (Stanat, 2005). Zhou and Belk (2004, p. 64) and others, for example, suggest among some Chinese there is a "yearning for status goods for the sake of the mianzi (prestige face) aspect rather than the lian (moral face) aspect of face which is related to a desire for reputation from success and can be signified by the visible consumption of luxury goods". An excellent example of the new conspicuous consumption in China is that luxury car makers, including Britain's Bentley, a unit of Volkswagen AG, have seen sales surge in China as racing economic growth creates wealthy elite (China Daily, 2006). Indeed, Wee (1997) reports that the fast accumulation of wealth and the concomitant rapid increase in the Chinese standard of living have stimulated many wealthy Chinese to pursue conspicuous consumption. It is the mianzi aspect related to reputation from success that promotes the desire for ostentatious luxury (Zhou and Belk, 2004).

Extant research on money attitudes has recognized the link between money attitudes and consumers' excessive preoccupation with achievement (i.e., achievement vanity). Money is viewed as a sign of achievement success (Tang, 1993). Murray (1938) stated that money behavior reflects needs for achievement, acquisition, and recognition. Those who are more concerned about how money can be used for power and prestige to impress others and project success are predisposed to view money in an instrumental way for achieving these ends. Hence, those who have a high degree of vanity in terms of achievements are likely to recognize the utilitarian role that money can

Journal of Consumer Marketing, Vol 27, No. 2 (2010): pg. 169-179. DOI. This article is @ Emerald and permission has been granted for this version to appear in e-Publications@Marquette. Emerald does not grant permission for this article to be further copied/distributed or hosted elsewhere without the express permission from Emerald. 
play in satisfying their vanity needs. On the basis of this research we propose the following research expectation:

RE4. There will be a significant relationship between the powerprestige dimension of MAS and achievement view dimension of vanity for young Chinese.

\section{Method}

Data for this study were gathered from young Chinese consumers. A convenience sample of these consumers was selected in a major city. The standard procedure for survey translation, including translation and back translation using bilingual experts, was followed prior to survey administration. A total of 127 consumers provided the data. The average age is 20.5 years; males comprise 55 percent of the sample.

The survey employed the MAS, where all scale items were measured using seven-point rating scales ( $1=$ Never and $7=$ Always). The survey also included the six-item materialism measure that was proposed by Richins in 1987 (see Richins and Dawson, 1992). These six items measure the success trait of materialism (Richins, 2004). The achievement view dimension of vanity was measured using Netemeyer et al.'s (1995) vanity scale. This scale consisted of five items and measured self-assessment of professional achievements (i.e., achievement view). All five items of achievement vanity were measured using seven-point Likert scales ( 1 = strongly disagree and 7 $=$ strongly agree). The items describing various scales are:

1. Items measuring power-prestige dimension of money attitudes[1]:

- I use money to influence other people to do things for me.

- I purchase things because I know they will impress others.

- I own nice things in order to impress others.

- I behave as if money were the ultimate symbol of success.

- I enjoy telling people about the money I make.

Journal of Consumer Marketing, Vol 27, No. 2 (2010): pg. 169-179. DOI. This article is (C) Emerald and permission has been granted for this version to appear in e-Publications@Marquette. Emerald does not grant permission for this article to be further copied/distributed or hosted elsewhere without the express permission from Emerald. 
NOT THE PUBLISHED VERSION; this is the author's final, peer-reviewed manuscript. The published version may be accessed by following the link in the citation at the bottom of the page.

- People that know me tell me that I place too much emphasis on the amount of money people have as a sign of their success.

- I find that I seem to show more respect to those people who possess more than I do.

- I tend to judge people by their money rather than their deeds.

- I try to find out if other people make more money than I do.

2. Items measuring distrust dimension of money attitudes:

- I complain about the cost of things I buy.

- It bothers me when I discover I could have gotten something for less elsewhere.

- After buying something, I wonder if I could have gotten the same for less elsewhere.

- I automatically say, "I cannot afford it," whether I can or not.

- When I buy something, I complain about the price I paid.

- I hesitate to spend money, even on necessities.

- When I make a major purchase, I have a suspicion that I have been taken advantage of.

3. Items measuring anxiety dimension of money attitudes[2]:

- It is hard for me to pass up a bargain.

- I am bothered when I have to pass up a sale.

- I spend money to make myself feel better.

- I show signs of anxiety when I do not have enough money.

- I show worrisome behavior when it comes to money.

- I worry about not being financially secure.

Journal of Consumer Marketing, Vol 27, No. 2 (2010): pg. 169-179. DOI. This article is (C) Emerald and permission has been granted for this version to appear in e-Publications@Marquette. Emerald does not grant permission for this article to be further copied/distributed or hosted elsewhere without the express permission from Emerald. 
NOT THE PUBLISHED VERSION; this is the author's final, peer-reviewed manuscript. The published version may be accessed by following the link in the citation at the bottom of the page.

4. Items measuring materialism:

- It is important to me to have really nice things.

- I would like to be rich enough to buy anything I want.

- I would be happier if I could afford to buy more things.

- It sometimes bothers me quite a bit that I cannot afford to buy all the things I want.

- People place too much emphasis on material things.

- It's really true than money can buy happiness.

5. Items measuring achievement-view vanity[3]:

- In a professional sense, I am a very successful person.

- My achievements are highly regarded by others.

- I am an accomplished person.

- I am a good example of professional success.

- Others wish they were as successful as me.

\section{Results}

Data were first analyzed using confirmatory factor analysis to examine psychometric properties of the measures. At the outset, separate analyses were performed on MAS, materialism, and achievement vanity scales to assess their dimensionality. These results are presented in Table I. For acceptable fit of any confirmatory factor model, high values for Tucker- Lewis Index (TLI), Comparative Fit Index (CFI), Iterative Fit Index (IFI), and a low value for Root Mean Square Residual (SRMR) are desired. Judging by these yardsticks, the confirmatory factor model which assumes that MAS consists of three distinct yet correlated dimensions of power-prestige, distrust, and anxiety produced acceptable fit indices. The one-dimensional materialism scale and the one-dimensional achievement view vanity scale models produced relatively better fit indices.

Journal of Consumer Marketing, Vol 27, No. 2 (2010): pg. 169-179. DOI. This article is @ Emerald and permission has been granted for this version to appear in e-Publications@Marquette. Emerald does not grant permission for this article to be further copied/distributed or hosted elsewhere without the express permission from Emerald. 
Next, we performed a confirmatory factor analysis that included all items from the three- dimensional MAS, one-dimensional materialism, and one-dimensional achievement view vanity scales. In this analysis, we obtained the fit of a five dimensional factor model and examined correlations among all five dimensions. The purpose of this analysis is to assess discriminant validity of our survey measures. Specifically, if the 95 percent confidence intervals around correlations of those scale dimensions did not contain the value " 1 ", then we can conclude that the scale dimensions have discriminant validity. Indeed, results revealed that none of the confidence intervals contained the value " 1 ", so we say that the MAS, materialism, and achievement vanity scales have discriminant validity. Subsequently, we examined composite reliability estimates of various measures. These estimates are as follows: 0.73 for power- prestige, 0.68 for distrust, 0.68 for anxiety, 0.68 for materialism, and 0.80 for achievement view vanity. While a reliability estimate of 0.70 or above indicates good fit, values above 0.60 are considered psychometrically adequate for research (Diamantopoulos and Siguaw, 2000; Malhotra, 2007). Given these acceptable psychometric properties of the different measures reported above, we formed composite indices of the three MAS dimensions (i.e., power- prestige, distrust, and anxiety), materialism, and achievement view vanity by averaging responses to individual scale items.

The next part of the analysis was aimed at examining the research expectations. We computed correlations among the composite indices and used them as inputs for path analysis. Results of this path analysis, shown in Figure 1, form the basis for evaluating our research expectations. Our first set of research expectations involved money attitude scale dimensions and materialism. We expected significant relationships between power-prestige and materialism as well as between anxiety and materialism. As shown in Figure 1, the concerned path estimates are indeed significant. We did not expect a relationship between distrust and materialism. Indeed, this path coefficient turned out to be insignificant. These results support $R E 1, R E 2$, and $R E 3$.

Intuitively, it seems clear that those who are high in materialism are likely to view money as the source that will give them power and prestige in the material gains they make. Moreover, those who are materialistic are likely to see money as the necessary ingredient they

Journal of Consumer Marketing, Vol 27, No. 2 (2010): pg. 169-179. DOI. This article is (C) Emerald and permission has been granted for this version to appear in e-Publications@Marquette. Emerald does not grant permission for this article to be further copied/distributed or hosted elsewhere without the express permission from Emerald. 
need to acquire material goods; not having money to achieve materialistic goals is likely to aggravate one's anxiety about the need for money. Lack of a significant relationship between distrust and materialism indicates that materialism was not involved in creating feelings of hesitancy, suspiciousness, and doubt regarding situations involving money and a lack of faith in one's ability to make efficient purchase decisions.

Next, we expected a significant relationship between powerprestige and achievement view vanity. The path coefficient for this relationship is also significant, thus supporting $R E 4$, albeit at the 0.10 level. This result suggests that achievement view vanity is connected to a feeling that money is a symbol of success and that it gives people the power to influence and impress others. In sum, results of path analysis indicate significant relationships among MAS scale dimensions, materialism, and achievement view vanity in the young Chinese consumer sample.

\section{Discussion and implications}

The results of this study show that attitudes towards money and the impact of these attitudes on psychological outcomes are not monolithic among the Chinese in this sample. Instead, young Chinese consumers view money as the means by which power and prestige can be displayed which confirms McClelland's (1961) understanding of achievement. Yet, money also represented something that deals with distrust and anxiety. Attitudes toward money clearly have an impact on materialism, specifically with the dimensions concerning power and prestige and anxiety. As expected, the power-prestige dimension of money attitudes is also related to achievement view. Given these findings, one can now ask about their relevance to China.

Noteworthy concern has appeared in the media about the new generation of Chinese consumers. Unlike the older generations that were subjected to the ideals of Communism under the Marxist dictum "from each according to his ability, to each according to his needs", the new generation has been allowed to embrace modernity. The Mao suit that described the mandated dress of the Chinese 25 years ago has been replaced by individual expression in fashion and taste. The young Chinese consumers are likely to model the attitudes of young people found in post-industrial societies. Indeed, young Chinese are

Journal of Consumer Marketing, Vol 27, No. 2 (2010): pg. 169-179. DOI. This article is (c) Emerald and permission has been granted for this version to appear in e-Publications@Marquette. Emerald does not grant permission for this article to be further copied/distributed or hosted elsewhere without the express permission from Emerald. 
likely to become part of the global segment that seeks fulfillment from consumption of the latest goods and trends.

The results of this study show that young Chinese regard money as a source of power and prestige. This attitude is in significant contrast to earlier generations which were prohibited from such thoughts. With money comes the ability to express oneself and to feel more important. This tendency was demonstrated in our study via the association between power- prestige dimension of money attitudes and achievement view vanity.

What do these results say about the future? The new order of China is seeing the ascendancy (politically and socially) of the "moneyed urban middle class" - a movement that the government is encouraging (Rosen, 2004). Material success is a source of this status which is giving rise to growing social stratification. Indeed, Chinese yuppies have become the "new publicized role models" (Rosen, 2004); the "Bobo" segment discussed earlier is a testimony to the new role models. There is now open acceptance of this new materialism in China as reflected in the more openly expressed attitudes and behavior of upwardly mobile Chinese youth (Rosen, 2004).

Commercial and marketing interests can view these findings with pragmatic implications. Featuring how money can be accessed through credit cards or loans may stimulate some Chinese to fulfill their desire to obtain money. Positioning products as a reflection of those having money to indulge such tastes may resonate well with some consumers. Advertising how the good life is possible with the possession of money could be linked to the use of credit cards or loans to acquire money. Clearly, clever marketing practitioners could develop motivational appeals in ads to feature the power of money to buy distinction in product ownership or in the use of services.

As China evolves during its dramatic metamorphosis in its economy and culture, money has become the currency of those who wish to be modern and successful. Money permits one to attain not only status and possessions but power and control of others - all of which contributes to increased materialism and expressions of vanity. The impact of this "new society" in China is likely to have dysfunctional consequences for the harmony of society. Sociologists are warning that the increasing inequalities and skewed incomes distribution will 
fracture society (Rosen, 2004). The drive for money is likely to create a singular mindset among some Chinese where greed and narrow selfinterests are likely outcomes. But what role should society play in constraining this desire for money?

At one time, cultural forces such as Confucian ideals and Buddhism gave a different set of perspectives and direction in life. Discontent with the prevailing mania for money can be seen in the search for a deeper meaning among some disaffected Chinese. Fan (2007), for example, reports that Confucianism is seeing resurgence in China as increasing numbers of Chinese seek an alternative to rampant materialism and obsession with money. Confucianism is viewed as a philosophy that can promote a return to traditional values and as a countervailing force opposing the Chinese preoccupation with money.

Given that these traditional forces have either disappeared in Communist China or have waned considerably, some institution may serve as a countervailing force. Can government play such a role? Is government likely to view the desire for money as an unhealthy situation as it did during the days of Mao? It is difficult to imagine that the Chinese government will play any role in this matter when growth is the singular purpose of its economic order. If the pursuit of money can motivate people to help the economy grow, the government is not likely to impede such a force. Since there are no noteworthy consumer advocacy groups in or agencies in China (unlike the FTC in the USA), vocal discussion about this topic from such institutions is virtually impossible. Alternatively, independent organizations that seek to reform society may play a role in raising consciousness about the mania for money. Perhaps, schools can impart another way of thinking where the dangers in the pursuit of money are examined in a more philosophical context. Lastly, parents may wish to intervene and direct their children to a more balanced life. One example is a literary editor who published a book, I'm Mediocre, I'm Happy, as a protest against education for material success goals only (Rosen, 2004). This book discusses how the author raised his talented daughter to pursue happiness above conventional success aimed at acquiring money. Perhaps, a grass roots movement is necessary in China that will empower parents to socialize their children differently and teach them about the dysfunctions coming from blind desire for money.

Journal of Consumer Marketing, Vol 27, No. 2 (2010): pg. 169-179. DOI. This article is (C) Emerald and permission has been granted for this version to appear in e-Publications@Marquette. Emerald does not grant permission for this article to be further copied/distributed or hosted elsewhere without the express permission from Emerald. 
It is likely that money will take on even more importance as the Chinese economy evolves and a society continues to splinter into "haves" vs "have-nots". The possession of money gives one greater access to the world of "haves" where money gives one distinction and identity. Media has reported that with the collapse of the Communist ideals a vacuum has developed in terms of the "meaning of life" and growing alienation. Communist ideals established meaning of life for all in the previous era where private possessions were unimportant, and wealth (which was largely state-owned) was for the benefit of all. In this relatively new era of globalization in China, if young Chinese consumers imitate the behavior of young adults in the West, then our results clearly portend what is likely to happen to future generations of young Chinese in terms of compulsive buying and other maladies endemic in consumer society.

Young Chinese consumers are likely to fill this vacuum through the drive for money, which once accumulated, will allow for expressions of vanity and materialism. Social commentators are likely to be discussing the crass drive for money in the future. It is likely that similar discussion will develop in other countries such as India, Indonesia, Vietnam and Malaysia as their economies develop and the desire for money accelerate. This study gives a glimpse of what is to come in China and perhaps in other countries. Will Madonna's lyrics ring true elsewhere?

\section{Future research}

While our study shows important relationships among money attitudes, materialism, and vanity, the findings are based on a sample of young consumers that are from one major city in China. Hence, future studies should re-examine these relationships with samples selected from other cities and consumer segments. Different sampling frames would enable policy makers to formulate a better strategy to address the negative outcomes of obsession with money.

Also, are the relationships found in this study likely to vary in India and across other developing countries in Asia? What is the relationship between money attitudes and compulsive buying? While studies done in the USA established such a relationship, we do not know whether it is present in China. Another area of needed research is in developing a comprehensive model of money attitudes, 
materialism, vanity, compulsive buying, and their possible antecedents or moderators. Such factors may include a number of sociological and psychological variables. Indeed, the body of knowledge on money attitudes is incomplete because many questions are yet to be addressed.

\section{Notes}

1. All money attitudes items are measured on a 1 (Never) to 7 (Always) scale.

2. All materialism items are measured on a 1 (Strongly disagree) to 7 (Strongly agree) scale.

3. All achievement view vanity items were measured on a 1 (Strongly disagree) to 7 (Strongly agree) scale.

\section{About the authors}

- Srinivas Durvasula is Professor and Edward A. Brennan Chair in Marketing at Marquette University in Wisconsin. He has also been on the faculty at Vrije University, the Netherlands and the National University of Singapore. He also served as a visiting professor at the Tinbergan Institute, The Netherlands. His research interests include modeling, measurement theory and cross-national studies on consumer behavior and advertising perceptions. He has published over 40 refereed articles, including those in the Journal of Consumer Research, Journal of Marketing Research, Journal of International Business Studies, Journal of Retailing, Journal of Advertising, Journal of Public Policy and Marketing, Journal of Consumer Affairs, Journal of Consumer Marketing, and European Journal of Marketing. Srinivas Durvasula is the corresponding author and can be contacted at: srinivas.durvasula@marquette.edu

- Steven Lysonski is Professor of Marketing and Miles Research Scholar at Marquette University in Wisconsin. He has been on the faculty at the University of Rhode Island, Copenhagen School of Business and Economics, and the University of Canterbury in New Zealand. He has published over 50 refereed articles in journals such as Journal of Marketing, Journal of Consumer Research, Journal of Consumer Affairs, Journal of Product Management, Journal of Advertising, Journal of Consumer Marketing, European Journal of Marketing, and International Journal of Research in Marketing. His

Journal of Consumer Marketing, Vol 27, No. 2 (2010): pg. 169-179. DOI. This article is (C) Emerald and permission has been granted for this version to appear in e-Publications@Marquette. Emerald does not grant permission for this article to be further copied/distributed or hosted elsewhere without the express permission from Emerald. 
research interests are in the areas of cross-cultural marketing, product management, and consumer behavior.

\section{References}

Abraham, K. (1965), "The spending of money in anxiety states", in Southerland, J.D., Bryan, D. and Strachey, A. (Eds), Selected Papers of Karl Abraham, Hogarth Press, London.

Belk, R. (1985), "Materialism: trait aspects of living in the material world", Journal of Consumer Research, Vol. 12, December, pp. 265-80.

Bell, M.M. (1998), An Invitation to Environmental Sociology, Pine Forge Press, Thousand Oaks, CA.

China Daily (2006), "Foreign luxury cars sales boom in China", available at www.chinadaily.com.cn/bizchina/2006-11/22/content_739464.htm (accessed November 24, 2006).

Crosby, F. (1982), Relative Deprivation and Working Women, Oxford University Press, New York, NY.

Crump, T. (1981), The Phenomenon of Money, Routledge \& Kegan Paul, London.

Crump, T. (1992), "Money as a ritual system", American Behavioral Scientist, Vol. 35 No. 6, pp. 669-77.

Diamantopoulos, A. and Siguaw, J.A. (2000), Introducing LISREL, Sage Publications, London.

d'Astous, A. and Tremblay, S. (1989), The Meaning of Things, Cambridge University Press, New York, NY.

Desarbo, W.S. and Edwards, E. (1996), "Typologies of compulsive buying behavior: a constrained clusterwise regression approach", Journal of Consumer Psychology, Vol. 5 No. 3, pp. 231-62.

Dholakia, R.R. and Levy, S.L. (1987), "The consumption dream in the United States: aspirations and achievements in a changing environment", Journal of Macromarketing, Vol. 7, Fall, pp. 41-51.

Doyle, K. (1999), The Social Meaning of Money, Sage Publications, London.

Fan, M. (2007), "Confucius making a comeback in money-driven modern China", Washington Post.com, July24, p. A01.

Freud, S. (1959) in Stranchey, J. (Ed.), Character and Eroticism, in Complete Psychological Works, standard ed., Vol. 9, Hogarth Press, London.

Journal of Consumer Marketing, Vol 27, No. 2 (2010): pg. 169-179. DOI. This article is (C) Emerald and permission has been granted for this version to appear in e-Publications@Marquette. Emerald does not grant permission for this article to be further copied/distributed or hosted elsewhere without the express permission from Emerald. 
NOT THE PUBLISHED VERSION; this is the author's final, peer-reviewed manuscript. The published version may be accessed by following the link in the citation at the bottom of the page.

Furnham, A. and Lewis, A. (1986), The Economic Mind: The Social Psychology of Economic Behavior, Wheatsheaf Books, Brighton.

Furnham, A. and Argyle, M. (1998), The Psychology of Money, Routledge, London.

Goldberg, H. and Lewis, R.T. (1978), Money Madness: The Psychology of Saving, Spending, Loving and Hating Money, William Morrow and Co., New York, NY.

Gupta, N. and Shaw, J.D. (1998), "Let the evidence speak: financial incentives are effective!", Compensation and Benefits Review, Vol. 26, March/April, pp. 28-32.

Johansson, P. (2001), "Selling the modern woman: consumer culture and Chinese gender politics", in Munshi, S. (Ed.), Images of the Modern Woman in Asia: Global Media and Local Meaning, Curzon Press, Richmond, pp. 94-122.

Keaveny, T.J. and Inderrierden, E.J. (2000), "Gender differences in pay satisfaction and pay expectations", Journal of Management Studies, Vol. 12 No. 3, pp. 363-79.

Lau, S. (1998), "Money: what it means to children and adults", Social Behavior and Personality, Vol. 26 No. 3, pp. 297-306.

Lea, S.E.G., Webly, P. and Walker, C.M. (1995), "Psychological factors in consumer debt: money management, economic socialization, and credit use", Journal of Economic Psychology, Vol. 16 No. 4, pp. 681701.

McBride, S. (1997), "Young deadbeats pose problems for credit-card issuers", Wall Street Journal, Vol. 28, November, p. B1, B10.

McClelland, D. (1961), The Achieving Society, Princeton University Press, Princeton, NJ.

Malhotra, N.K. (2007), Marketing Research: An Applied Orientation, 5th ed., Prentice Hall, Upper Saddle River, NJ.

Marquand, R. (2004), "Love and money reshape family in China", Science Christian Monitor, December 15.

Murray, H.A. (1938), Exploration in Personality, Oxford University Press, New York, NY.

Netemeyer, R., Burton, S. and Lichtenstein, D.R. (1995), "Trait aspects of vanity: measurement and relevance to consumer behavior", Journal of Consumer Research, Vol. 21, March, pp. 612-25.

Journal of Consumer Marketing, Vol 27, No. 2 (2010): pg. 169-179. DOI. This article is @ Emerald and permission has been granted for this version to appear in e-Publications@Marquette. Emerald does not grant permission for this article to be further copied/distributed or hosted elsewhere without the express permission from Emerald. 
NOT THE PUBLISHED VERSION; this is the author's final, peer-reviewed manuscript. The published version may be accessed by following the link in the citation at the bottom of the page.

Pfeffer, J. (1998), "Six dangerous myths about pay", Harvard Business Review, May/June, pp. 108-19.

Richins, M.L. (2004), "The material values scale: a re-inquiry into its measurement properties and the development of a short form", Journal of Consumer Research, Vol. 31, June, pp. 209-19.

Richins, M.L. and Dawson, S. (1992), "A consumer values orientation for materialism and its measure: scale development and validation", Journal of Consumer Research, Vol. 19, December, pp. 522-33.

Roberts, J.A. (1998), "Compulsive buying among college students: an investigation of its antecedents, consequences, and implications for public policy", The Journal of Consumer Affairs, Vol. 32 No. 2, pp. 295319.

Roberts, J.A. and Jones, E. (2001), "Money attitudes, credit card use, and compulsive buying among college students", Journal of Consumer Affairs, Vol. 35 No. 2, pp. 213-40.

Roberts, J.A., Sepulveda, M. and Cesar, J. (1999), "Demographics and money attitudes: a test of Yamuchi and Templer's money attitude scale in Mexico", Personality and Individual Differences, Vol. 27 No. 1, pp. 1935.

Rosen, S. (2004), "The victory of materialism: aspirations to join China's urban moneyed classes and the commercialization of education", The China Journal, Vol. 51, January, pp. 27-51.

Rubenstein, C. (1981), "Money and self-esteem, relationships, secrecy, envy, satisfaction", Psychology Today, Vol. 15 No. 5, pp. 29-44.

Shaw, J.M., Duffy, M.K., Jenkins, D. and Gupta, N. (1999), "Positive and negative affect, signal sensitivity and pay satisfaction", Journal of Management, Vol.25 No. 2, pp. 189-206.

Simmel, G. (1997), The Philosophy of Money, Routledge \& Kegan Paul, London, (originally published in 1900).

Snelders, H., Hussein, G., Lea, S. and Webley, P. (1992), "The polymorphous concept of money", Journal of Economic Psychology, Vol. 13 No. 1, pp. 71-92.

Solomon, M.R. (1985), The Psychology of Fashion, Heath, Lexington, MA.

Solomon, M.R. (1992), Consumer Behavior: Buying, Having, and Being, Allyn \& Bacon, Needham Heights, MA.

Journal of Consumer Marketing, Vol 27, No. 2 (2010): pg. 169-179. DOI. This article is (C) Emerald and permission has been granted for this version to appear in e-Publications@Marquette. Emerald does not grant permission for this article to be further copied/distributed or hosted elsewhere without the express permission from Emerald. 
NOT THE PUBLISHED VERSION; this is the author's final, peer-reviewed manuscript. The published version may be accessed by following the link in the citation at the bottom of the page.

Spenner, K.I. and Featherman, D.L. (1978), "Achievement ambitions", Annual Review of Sociology, Vol. 4, pp. 373-420.

Stanat, M. (2005), China's Generation Y: Understanding the Future Leaders of the World's Next Superpower, Homa and Sekey Books, Paramus, NJ.

Tang, T.L.P. (1992), "The meaning of money revisited", Journal of Organizational Behavior, Vol. 13, pp. 197-202.

Tang, T.L.P. (1993), "The meaning of money: extension and explorations of the money ethic scale in a sample of university students in Taiwan", Journal of Organizational Behavior, Vol. 14, pp. 93-9.

Tang, T.L.P., Furnham, A. and Davis, G.M.T. (2000), "A cross-cultural comparison of pay differentials as a function of rater's sex and the money ethic endorsement: the Mathew effect revisited", Personality and Individual Differences, Vol. 29, pp. 685-97.

Thozhur, S.M., Riley, M. and Szivas, E. (2006), "Money attitudes and pay satisfaction of the low paid", Journal of Managerial Psychology, Vol. 21 No. 2, pp. 163-72.

Valence, G., d'Astous, A. and Fortier, L. (1988), "Compulsive buying: concept and measurement", Journal of Consumer Policy, Vol. 11 No. 4, pp. 419-33.

Veblen, T. (1976), Theory of the Leisure Class, Macmillan, New York, NY.

Yamuchi, K. and Templer, D. (1982), "The development of a money attitudes scale", Journal of Personality Assessment, Vol. 46 No. 5, pp. 522-8.

Yue, P. (2007), "Green China and young China", Chinadialogue.com, July 17.

Wang, J. (2005), "Bourgeois bohemians in China? Neo-tribes and the urban imagery", China Quarterly, Vol. 183, September, pp. 532-48.

Wee, C.H. (1997), Practical Marketing: An Asian Perspective, Addison Wesley, Singapore.

Wiseman, T. (1974), The Money Motive, Hodder \& Stoughton, London.

Zhou, N. and Belk, R. (2004), "Chinese consumer readings of global and local advertising appeals", Journal of Advertising, Vol. 33 No. 3, pp. 63-76.

Journal of Consumer Marketing, Vol 27, No. 2 (2010): pg. 169-179. DOI. This article is (c) Emerald and permission has been granted for this version to appear in e-Publications@Marquette. Emerald does not grant permission for this article to be further copied/distributed or hosted elsewhere without the express permission from Emerald. 
NOT THE PUBLISHED VERSION; this is the author's final, peer-reviewed manuscript. The published version may be accessed by following the link in the citation at the bottom of the page.

\section{Appendix}

Table I Dimensionality of money attitudes, materialism, and achievement view vanity

\begin{tabular}{|c|c|c|c|c|c|c|}
\hline Scale & $\chi^{2}$ & $d f$ & TLI & $\mathrm{CFI}$ & IFI & Std RMR \\
\hline Three-dimensional money attitude scale (power-prestige, distrust, anxiety) & 346.59 & 206 & 0.85 & 0.86 & 0.86 & 0.08 \\
\hline One-dimensional materialism scale & 11.9 & 9 & 0.96 & 0.98 & 0.98 & 0.05 \\
\hline One-dimensional achievement view vanity scale & 9.93 & 5 & 0.97 & 0.99 & 0.99 & 0.03 \\
\hline
\end{tabular}

Figure 1 Path model showing relationships among dimensions of money attitude, materialism, and achievement vanity

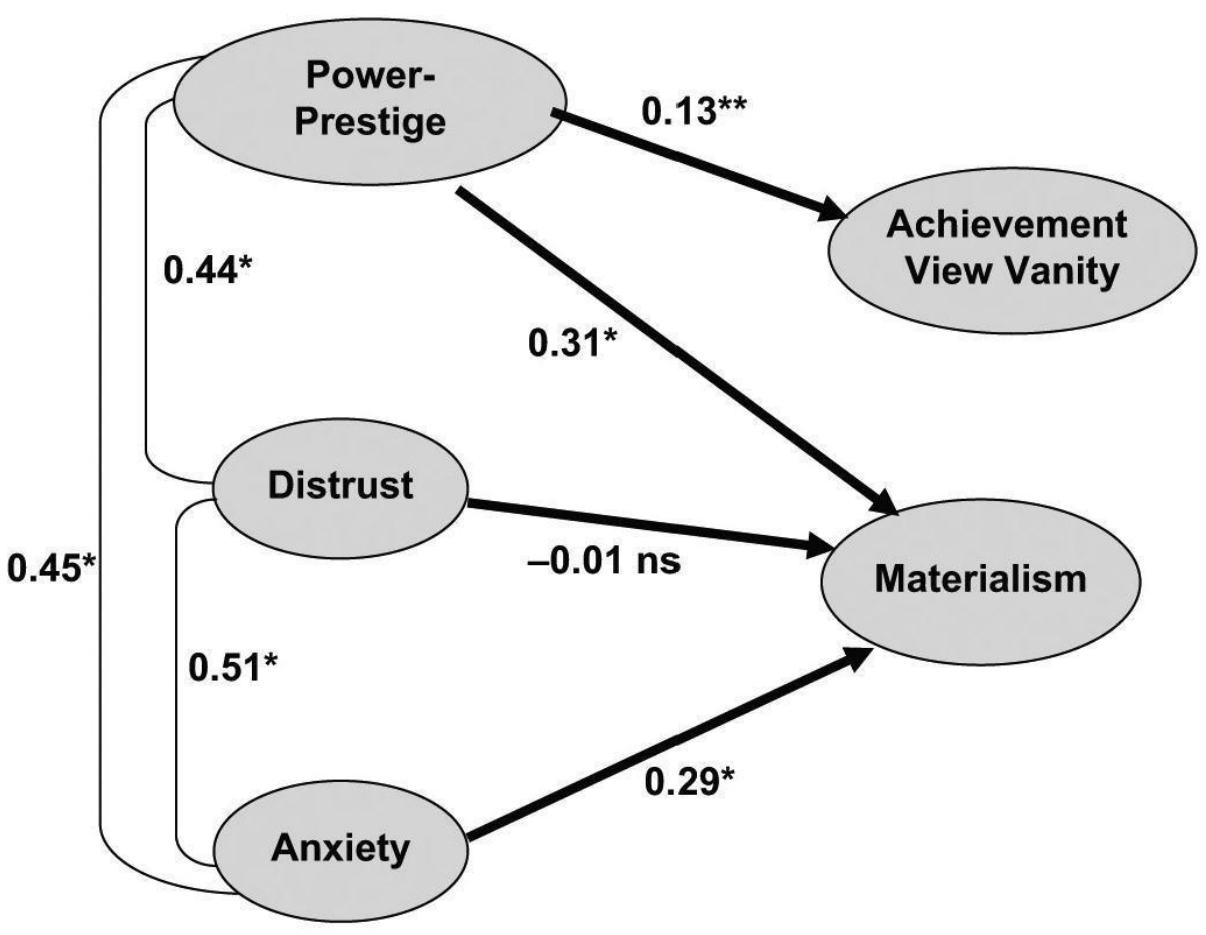

Notes: *Indicates significance at 0.05 level and $* *$ indicates significance at 0.10 level; ns: indicates non- significant path estimate. Model Fit Indices: $X 2(3)=9.81$; CFI $=0.95 ;$ IFI $=0.95 ;$ SRMR $=0.06$ 
NOT THE PUBLISHED VERSION; this is the author's final, peer-reviewed manuscript. The published version may be accessed by following the link in the citation at the bottom of the page.

\section{Executive summary and implications for managers and executives}

This summary has been provided to allow managers and executives a rapid appreciation of the content of the article. Those with a particular interest in the topic covered may then read the article in toto to take advantage of the more comprehensive description of the research undertaken and its results to get the full benefit of the material present.

Money has become central within many market-oriented countries. Analysts have noted the role of money in shaping the thoughts and behaviors of consumers, and its ability to influence social and cultural interactions. In this respect, the meaning of money is deemed to go beyond economics into areas that include the formation and maintenance of social identities.

Marketing's portrayal of certain lifestyles and possessions as desirable or idealistic has ascribed money with symbolic value. Consumers who desire to signal their status within society use money to purchase the material goods that help create the self they wish to portray to others. In addition to such pursuits of vanity, experts argue that obsessions with money are inextricably linked with materialistic or hedonistic desires that are prevalent within Western cultures.

\section{Important issues to consider}

The ongoing transformation of China from state-controlled society into a more free market economy has prompted suggestions of corresponding changes within the psyche of its inhabitants. More specifically to this context, the perception of money has altered to the extent that respondents in one study valued it at least the equal of friendship and ideas. Other significant developments include a growing emphasis on individual achievement and new higher income classes boasting the buying power needed to purchase expensive and luxury items.

Different researchers are claiming that younger Chinese consumers are been influenced by the country's "nouveaux riche" and are too becoming preoccupied with money and the opportunities it seemingly bestows upon those with access to significant amounts. It is alleged that money-related issues permeate magazines targeting Chinese youth. Other scholars point out that the economic and societal shift has given rise to a new breed of consumer whose pursuit of money is motivated by vanity and materialistic goals.

A consideration of earlier developments elsewhere can illustrate the impact of attitudes towards money. In the USA, for instance, children acquire an interest in and understanding of money from a very young age. This

Journal of Consumer Marketing, Vol 27, No. 2 (2010): pg. 169-179. DOI. This article is (C) Emerald and permission has been granted for this version to appear in e-Publications@Marquette. Emerald does not grant permission for this article to be further copied/distributed or hosted elsewhere without the express permission from Emerald. 
NOT THE PUBLISHED VERSION; this is the author's final, peer-reviewed manuscript. The published version may be accessed by following the link in the citation at the bottom of the page.

provides the basis for motivations in later life, reflected in numerous studies indicating that both teenagers and adults view making money as their most important goal.

Scholars have also found that perceptions of money can influence spending habits, political beliefs and views on the environment. And according to others, such attitudes may have a greater impact on work-related issues than demographic factors like age, gender or education. Marketers will also be aware of how a modern outlook on money can trigger the compulsive buying tendencies that exists among today's young adults raised to value instant gratification. The association of such behavior with personal debt, depression, anxiety and poor self-esteem is noted too.

Previous research into money attitudes has revealed associations of money with goodness, evil, respect and freedom among other meanings. The varying perceptions are captured in the money attitude scale (MAS), comprising four key dimensions:

1. Power prestige. A high rating here indicates money is used to symbolize success and influence, and to dominate and/or impress others. Scholars believe that links to compulsive buying exist because individuals seeking to flaunt their status are forced to consume more and more expensive material goods in order to remain ahead of others with similar ambitions. Marketers exploit these desires by frequently incorporating status appeals into their messages.

2. Distrust. People scoring highly in this dimension are suspicious in money situations and lack confidence in their purchase decision making. Research suggests this consumer type is price sensitive, hesitant and "unlikely to indulge in excessive purchasing" behavior. Money is not equated with fulfillment to these consumers.

3. Anxiety. Money is simultaneously both a source of anxiety and a protection from anxiety to those scoring high here. Such consumers buy compulsively in their efforts to reduce anxiety. Having money induces a sense of security, while those without money feel more insecure.

4. Retention time. High scorers will plan their financial future and carefully monitor their financial situation.

A need to display personal achievement is another important factor. One way individuals accomplish this is through the conspicuous possession of certain products to emphasize the success their achievement has brought. Such tendencies are beginning to emerge in China, where prestige rather than morals is driving the consumption of status goods. The significant

Journal of Consumer Marketing, Vol 27, No. 2 (2010): pg. 169-179. DOI. This article is (C) Emerald and permission has been granted for this version to appear in e-Publications@Marquette. Emerald does not grant permission for this article to be further copied/distributed or hosted elsewhere without the express permission from Emerald. 
NOT THE PUBLISHED VERSION; this is the author's final, peer-reviewed manuscript. The published version may be accessed by following the link in the citation at the bottom of the page.

increase in the sale of luxury cars perfectly illustrates this development in a society where open displays of wealth were previously forbidden.

Durvasula and Lysonski explore these factors further in a survey of young Chinese consumers from a major city. Of the 127 respondents, 55 percent were males and the average was 20.5 years. The study used the MAS, although the retention time dimension was considered irrelevant and omitted. Other scales were employed to measure vanity and materialism. The data showed significant relationships between:

- power-prestige and materialism;

- anxiety and materialism; and

- power-prestige and achievement vanity.

These results were predicted as was the insignificant relationship that was found between distrust and materialism. One conclusion by the authors is that those rating high in materialism will see money as the tool with which to symbolize success and afford them power and status.

On this evidence, money attitudes seemingly produce different impacts on "psychological outcomes" on younger Chinese consumers. Nevertheless, it is still assumed that young people in China are likely to mimic the attitudes and behaviors of peer groups in more industrialized nations. The growing belief that money enables power and self-importance is reflected in the emergence of those that are serving as role models for youthful Chinese consumers.

\section{Implications for marketing and future research}

Marketers can, for example, promote the use of credit cards and loans as viable methods of accessing the money associated with goal achievement. Another option is to strategically advertise products as "a reflection of those having money to indulge such tastes". The authors point out that shrewd marketing to illustrate the link between money and the ownership or access to exclusive products or services can prove successful.

The potential for increased inequalities and other negative impacts on societal harmony as greed and self-interest takes hold are also acknowledged. Durvasula and Lysonski note the possibility that cultural forces will reemerge to "promote a return to traditional values" as an alternative to "rampant materialism". It is assumed that government guidance is unlikely as this would run counter to aims to stimulate strong economic growth. Instead, responsibility for ensuring children are made aware of becoming obsessed with the pursuit of money might rest predominantly with parents and schools.

Journal of Consumer Marketing, Vol 27, No. 2 (2010): pg. 169-179. DOI. This article is @ Emerald and permission has been granted for this version to appear in e-Publications@Marquette. Emerald does not grant permission for this article to be further copied/distributed or hosted elsewhere without the express permission from Emerald. 
NOT THE PUBLISHED VERSION; this is the author's final, peer-reviewed manuscript. The published version may be accessed by following the link in the citation at the bottom of the page.

Future investigations could consider a larger sample that includes representatives from other cities and consumer segments. Replicating the study within other developing nations like is also suggested. The authors likewise recommend that a comprehensive model incorporating each factor discussed here and possible antecedents or moderators should be created. 